\title{
Joint analysis of geodetic and earthquake fault-plane solution data to constrain magmatic sources: A case study from Kīlauea Volcano
}

\author{
Christelle Wauthier ${ }^{1,2 *}$, Diana C. Roman ${ }^{3}$, Michael P. Poland ${ }^{4}$
}

1. Department of Geosciences, Pennsylvania State University, USA

2. Institute for CyberScience, Pennsylvania State University, USA

3. Department of Terrestrial Magnetism, Carnegie Institution for Science, USA.

4. Cascades Volcano Observatory, U.S. Geological Survey, USA.

*Corresponding author: Christelle Wauthier, Department of Geosciences, Pennsylvania State University, USA (cuw25@psu.edu) 


\begin{abstract}
A joint analysis of geodetic and seismic datasets from Kîlauea Volcano during a period of magmatic unrest in 2006 demonstrates the effectiveness of this combination for testing and constraining models of magma dynamics for a complex, multi-source system. At the end of 2003, Kîlauea's summit began a four-year-long period of inflation due to a surge in magma supply to the volcano. In 2006, for the first time since 1982, Kîlauea's Southwest Rift Zone (SWRZ) also experienced inflation. To investigate the characteristics of active magma sources and the nature of their interactions with faults in the SWRZ during 2006, we integrate, through Coulomb stress modeling, contemporary geodetic data from InSAR and GPS with a new catalogue of double-couple fault-plane solutions for volcano-tectonic earthquakes. We define two periods of inflation during 2006 based on the rate of deformation measured in daily GPS data, spanning February to 15 March 2006 (Period 1) and 16 March to 30 September 2006 (Period 2). InSAR data for these two periods are inverted to determine the position, change in size, and shape of inflation sources in each period. Our new models are consistent with microseismic activity from each period. They suggest that, during Period 1, deformation in the SWRZ can be explained by pressurization of magma in a spherical reservoir beneath the south caldera, and that, during Period 2, magma was also aseismically intruded farther to the southwest into the SWRZ along a sub-horizontal plane. Our Coulomb stress analysis shows that the microseismicity recorded in the SWRZ is induced by overpressurization of the south caldera reservoir, and not by magma intrusion into the SWRZ. This study highlights the importance of a joint analysis of independent geophysical datasets to fully constrain the nature of magma accumulation.
\end{abstract}




\section{Introduction}

Knowledge of the location and volume of intruded magma is key for both eruption forecasting and the interpretation of volcano structure and dynamics. Magma pathways and storage regions can be assessed through modeling of geodetically-imaged deformation sources (e.g., [Dvorak and Dzurisin, 1997; Segall, 2010] and references therein). Analytical half-space geodetic models work well for volcanoes with simple magmatic systems with deformation sources that do not overlap in space and/or time. However, analytical geodetic models only place limited constraints on deformation sources in complex systems with multiple contemporaneously active sources like Kîlauea (Hawai'i) or Etna (Italy) (e.g., [Bonaccorso, 2002; Lundgren and Rosen, 2003; Bonforte et al., 2008; Poland et al., 2014]). When the geometry of the source(s) is complex or multiple sources are active at same time or place, other independent geophysical or geological datasets should be used to constrain geodetic models.

The physical processes that lead to ground deformation at restless volcanoes are also understood to drive microseismic activity in the form of volcano-tectonic (VT) earthquake swarms (e.g., [Roman and Cashman, 2006; Segall et al., 2013]). Even if geodesy and seismology are recognized as the most useful geophysical tools for volcano monitoring [Segall, 2013], they are very rarely used synergistically. A joint analysis of independent seismic and geodetic datasets can help constrain magma source characteristics at complex multi-source volcanoes. For example, Dieterich et al. [2003] calculated crustal stress changes independently from seismicity and geodetic modeling and showed that deep rift opening in addition to decollement slip was required in the three months following a dike injection at Kîlauea Volcano in 1983. Segall and Yun, 
[2005] and Segall et al. [2013] demonstrated that a joint inversion of seismic and geodetic datasets is useful for studying diking processes. In particular, the depth extent of a dike is poorly resolved by geodesy (especially Interferometric Synthetic Aperture Radar - InSAR - alone) but is much better constrained by joint inversion of geodesy and seismicity.

In this study, we present a new approach for joint analysis of geodetic and seismic data through Coulomb stress modeling, and we demonstrate how this approach allows us to refine models of the magmatic sources responsible for observed deformation and seismicity. Kîlauea Volcano is an ideal site to test this approach given the complexity of its magma plumbing system and the availability of various high-quality geophysical datasets. We use Coulomb stress modeling to link geodetic (InSAR + GPS) and VT earthquake fault-plane solution (FPS) observations for a period of complex system-wide unrest in 2006, which allows us to test previously published geodetic models for this period. We investigate two periods of inflation in 2006: February 1 - March 152006 (Period 1), and March 16 - September 30 (Period 2), corresponding to distinct inflation rates and deformation patterns.

\section{Background}

\subsection{Külauea Volcano}

Kîlauea (Figure 1) is a basaltic volcano characterized by rapid and high rates of deformation and intense seismic activity, especially associated with its mobile southern flank. This mobile flank is delimited by the volcano's two rift systems, which extend to the southwest (SWRZ) and east (ERZ) from the summit and are connected south of the 
summit by the Koa'e Fault System - a zone of north- and south-dipping normal faults between the two rift zones. Rift zones at Kỉlauea are defined as areas of normal faulting, open fractures, and eruptive fissures, and they are used as pathways for magma transport between the summit reservoir complex and the flanks of the volcano. The ERZ, which follows the main structural trend of the volcano [Johnson et al., 2015], has been the locus of eruptive activity at Kîlauea since the 1950s, whereas the shorter SWRZ has only experienced a few eruptions in the past 200 years [Poland et al., 2014]. While the ERZ manifests as a single feature centered around $3 \mathrm{~km}$ depth, the SWRZ is divided into a deeper ( $\sim 3 \mathrm{~km}$ center) "seismic" SWRZ (SSWRZ) to the south and a shallower $(\sim 1 \mathrm{~km}$ center) "volcanic" SWRZ (VSWRZ) to the north (e.g., [Poland et al., 2014; Wright and Klein, 2014], and references therein). The summit magma system includes two long-term reservoirs, one located at $\sim 3 \mathrm{~km}$ below the south caldera ( $\mathrm{SC}$, from which radiate the ERZ and SSWRZ) and a second located at $\sim 1 \mathrm{~km}$ below the eastern margin of Halema'uma'u crater (H, from which radiates the VSWRZ ) [Tilling and Dvorak, 1993; Pietruszka and Garcia, 1999; Cervelli and Miklius, 2003; Bagnardi et al., 2014; Poland et al., 2014].

\subsection{The 2003-2007 magma surge}

For the first 20 years of Kîlauea's 1983-present ERZ eruption, surface deformation was largely characterized by subsidence at the summit and along both rift zones [Poland et al., 2012, 2014]. At the end of 2003, however, Kīlauea's summit began a 4-year-long period of inflation that culminated in an ERZ dike intrusion and small eruption during 17-19 June 2007-the "Father's Day" (FD) event (Figure 2) [Poland et 
al., 2008; Montgomery-Brown et al., 2010]. On the basis of deformation, seismicity, and lava chemistry and temperature, the FD event was interpreted to be the result of forcible intrusion of magma driven by high pressure within the summit magma storage area, as opposed to a passive response to rifting [Poland et al., 2008, 2012; Montgomery-Brown et al., 2010]. During the 4 years of inflation preceding the FD event, lava effusion rates also increased, suggesting that the activity that culminated in the FD event was driven by a surge in the supply of magma from the mantle to the volcano [Poland et al., 2012; Anderson and Poland, 2016].

\subsection{Unusual activity in 2006 in the SWRZ}

The SWRZ had been gradually subsiding since the last eruptive episode in 1974, with the exception of episodes of dike injection accompanied by localized inflation in 1981-82 [Wright and Klein, 2014]. Beginning in mid-March 2006, however, the SWRZ began inflating (Figure 3). Two distinct periods of summit and upper SWRZ deformation can be defined based on daily GPS data (Figure 3): February 1 - March 152006 (Period 1, characterized by a high rate of inflation at AHUP, south of the summit caldera; and subtle deflation at KOSM, in the SWRZ), and March 16 - September 30 (Period 2, characterized by a lower rate of inflation at AHUP and inflation in the SWRZ). Seismicity rates in both the SWRZ and ERZ were strongly elevated during Period 1 (Figure 2c). The beginning of Period 2 corresponds to a switch from low rates of subsidence or no deformation to inflation in the SWRZ (Figure 3). Seismicity rates in both the upper ERZ and SWRZ remained moderately elevated during Period 2 (Figure 2c). Deformation during 2006 was recorded by ground-based GPS and InSAR data from 
the ENVISAT, RADARSAT-1 and ALOS-1 satellites.

\subsection{Existing geodetic models for the 2006 inflation}

Several geodetic models have been proposed to explain the inflation of the summit and SWRZ areas in 2006 at Kīlauea [Myer et al., 2008; Baker and Amelung, 2012; Poland et al., 2012] - see Table 1 for a summary. Myer et al. [2008] invert (separately) two ALOS-1 interferograms (2 May to 2 August 2006, and 22 June to 7 November 2006) to infer the source of deformation. This study does not investigate Period 1 and only partially covers Period 2. GPS data were used to calibrate the interferograms but were not included in the geodetic inversions. The Poisson's ratio was fixed to a value of 0.25 (Dave Myer, Pers. Comm., April 2016). The most likely model consists of a uniform opening (0.13-0.15 m) sill [Okada, 1985], 3-4 km wide, 8-9 km long, dipping $12-16^{\circ}$ to the $\mathrm{SW}$, and located at a depth of $1-2 \mathrm{~km}$ beneath the ground surface.

Poland et al. [2012] and Anderson and Poland [2016] investigate deformation during the entire year of 2006, covering both Periods 1 and 2, but not taking into account any time variability in the location, position, and/or number of deformation sources during 2006. An ENVISAT ascending interferogram (15 December 2005 - 31 December 2006) was inverted to infer the active deformation sources. The Poisson's ratio was fixed to a value of 0.25 . Poland et al. [2012] find that the most likely model sources for 2006 based on this interferogram are 1) an inflating reservoir [Mogi, 1958] located in the SC area at $2.9 \mathrm{~km}$ depth and inflating by $9 \times 10^{6} \mathrm{~m}^{3}$; and 2) a uniform opening $(0.65 \mathrm{~m})$ sill [Okada, 1985], $1.2 \mathrm{~km}$ wide, $4.8 \mathrm{~km}$ long, and located beneath the SWRZ at a depth of 
$3.8 \mathrm{~km}$ beneath the ground surface. Anderson and Poland [2016] also find a long, thin, southwest-striking rectangular inflating sill, at a depth of $4.5-4.9 \mathrm{~km}$ but with no additional source in the SC area.

Baker and Amelung [2012] investigate Periods 1 and 2 separately. The authors used a multi-temporal time-series InSAR method based on three RADARSAT-1 datasets acquired from different orbits and viewing angles. The Young's modulus and Poisson's ratio for their inversions are fixed to values of $30 \mathrm{GPa}$ and 0.25 , respectively. For Period 1 (8 February - 28 March 2006), their most likely model is an inflating circular sill (penny-shaped crack, [Fialko et al., 2001]) located in the SC area at a depth of 2.7-4.7 $\mathrm{km}$ with a radius of $1.3-4 \mathrm{~km}$ and inflating by $11.8 \times 10^{6} \mathrm{~m}^{3}$. For Period $2(28$ March -2 October 2006), their most likely model is a uniform opening $(\sim 0.7 \mathrm{~m})$ rectangular inflating sill [OKada, 1985], $2.2 \mathrm{~km}$ wide, $\sim 7 \mathrm{~km}$ long, and located at a depth of 2.9-4.2 $\mathrm{km}$ beneath the ground surface.

Poland et al. [2014] propose a model for Period 2 only. An ENVISAT ascending interferogram (13 May - 30 September 2006) and GPS data from four permanent stations were jointly inverted. The Young's modulus and Poisson's ratio are fixed to values of 30 GPa and 0.25 , respectively. Their most likely model for Period 2 is a sill [Okada, 1985] with a distributed opening (maximum of $0.6 \mathrm{~m}$ ), extending $\sim 5 \mathrm{~km}$ from the $\mathrm{SC}$ into the SWRZ and located at a depth of $3 \mathrm{~km}$ beneath the ground surface. There are two areas of significant opening: in the SC and beneath the SWRZ.

The competing geodetic models described above demonstrate the problem of nonuniqueness common to inversion and modeling of geodetic datasets. The only two studies that considered Period 1 as a distinct period disagree on the nature of the source: a point- 
source reservoir is used in Poland et al. [2012] versus a sill in Baker and Amelung [2012]. All existing models include a sill beneath the SWRZ during Period 2 (Table 1); however, they differ significantly in terms of depth, opening, geometry, and dip. Most published models do not consider an actively deforming source in the SC area in Period 2, however Poland et al. [2014] find significant opening in the SC area.

The fit of different models to observations of surface deformation in 2006 is difficult to assess or compare because different underlying data sets and different inversion methods are being used. Many published geodetic models are naïve in that they do not include earlier resolved sources (e.g., the SC source resolved by Poland et al. [2012] was not included in Baker and Amelung [2012]). Our approach to these issues, presented in the following two sections, is to: 1) use local earthquake FPS to independently test and constrain the geodetic models for both periods through Coulomb stress modeling and 2) consistently recalculate the fit of these models in each period using a joint geodetic dataset (GPS + InSAR)

\section{Fault-plane solution analysis}

We produced and analyzed a catalog of double-couple VT earthquake FPS for Kīlauea spanning Periods 1 and 2. For all VT earthquakes that were detected between February 1 and September 30, 2006, by the Hawaiian Volcano Observatory's (HVO) automated triggering routine and assigned a location near Kīlauea based on HVO analyst picks and locations, we repicked P-wave first-motion polarities and combined our polarity picks with the high-precision relative hypocentral location for the event determined by Matoza et al. [2013]. We then attempted to calculate a double-couple FPS 
based on first-motion polarities using the program FPFIT [Reasenberg and Oppenheimer, 1985]. The resulting FPS were evaluated for quality and rejected if they did not meet all of the following criteria (e.g., [Jolly et al., 1994; Giampiccolo et al., 1999]): unique or similar multiple solutions, misfit of no more than $15 \%$ of the P-wave polarities, station distribution ratio (a measure of data distribution around the hypocenter) $\geq 0.40$, uncertainty in strike, dip, and rake of $\leq 30^{\circ}$, and pressure (P-) and tension (T-) axis $95 \%$ confidence regions that cover $\leq 25 \%$ of the focal sphere. Waveform recordings of teleseisms were used to identify stations with reversed polarities during the study period, and all identified polarity reversals were accounted for during calculation of FPS.

The resulting FPS catalog contains 185 high-quality FPS, 97 of which are for earthquakes occurring during February 1-March 15, 2006 and 89 of which are for earthquakes occurring during March 16-September 30, 2006 (Figure 4). 70\% of the FPS in our catalog have no misfit polarities to the preferred solution. Fault-plane solutions for earthquakes in the ERZ show a predominance of strike-slip faulting with FPS P-axes primarily oriented WNW, radial to the caldera, while FPS for SWRZ earthquakes show a mix of oblique strike-slip and thrust faulting with P-axes predominantly oriented NE (also radial to the caldera). Fault slip in the Nāmakanipaio area (a region of persistent seismicity west of Kîlauea Caldera) is less well characterized, with a small number of high-quality FPS showing a mix of fault orientations and styles and P-axes dominantly oriented ESE to ENE, roughly radial to the caldera. There is no obvious change in style of faulting and p-axis orientation between Periods 1 and 2 in any of the three regions of seismicity. 


\section{Coulomb stress modeling of geodetic sources}

We link stresses produced by various geodetically-modeled inflation sources from the literature and those found in this study to strain expressed as brittle faulting (VT earthquakes) through calculation of Coulomb stress changes on faults whose strike, dip, and rake were determined from FPS. Using this approach, we can assess which inflation sources are most likely to result in the observed patterns of faulting (i.e., whether the inflation source results in large positive Coulomb stress changes on faults whose location, orientation, and sense of slip is well-constrained). We model Coulomb stresses using Coulomb 3.3 [Lin, 2004; Toda et al., 2005], which allows calculation of changes in Coulomb stress caused by an inflating rectangular dislocation or point source on faults of specified location, orientation, and sense of slip. All calculations are made in a homogeneous half-space with standard elastic moduli (shear modulus of $20 \mathrm{GPa}$, Poisson's ratio of 0.25 [Dieterich et al., 2003], and an effective coefficient of internal friction of 0.4 ) and no pore pressure changes or pre-existing stresses. We test different inflation sources for Period 1 including a) a horizontal sill and inflating reservoir taken from Poland et al. [2012], and b) a horizontal penny-shaped crack taken from Baker and Amelung [2012] (their source 4). For Period 2, we test a) an inflating horizontal sill taken

from Myer et al. [2008], b) the horizontal sill and inflating reservoir of Poland et al. [2012], and c) a horizontal penny-shaped crack taken from Baker and Amelung [2012] (their source 4). In all scenarios, we model inflation as instantaneous.

\subsection{Period 1}

Of the two existing Period 1 models tested, we find that the models which 
included a SC inflating reservoir ([Poland et al., 2012]) slightly outperformed the pennyshaped crack model of Baker and Amelung [2012]. Both models resulted in Coulomb stress increases of at least one bar at the locations of over $80 \%$ of the earthquakes in the East Rift Zone for which there are FPS. The Poland et al. [2012] model results in positive Coulomb stress changes for $64 \%$ of the SWRZ earthquakes, compared to $50-59 \%$ with the Baker and Amelung [2012] model (Figure 5). The similarity in results is probably because both models fundamentally require magma storage beneath the south caldera at 3-4 km depth, with only the modeled geometry differing between the studies. We note that neither of the existing Period 1 models resulted in strong Coulomb stress changes on Nāmakanipaio faults, indicating that earthquake activity in this area is likely not due to processes driving seismicity in the rift zones [Johnson et al., 2015].

\subsection{Period 2}

All existing models for Period 2 include a sill source, but only the Poland et al. (2012) model includes an inflating reservoir (Figure 5). Similar to Period 1, we find that the Poland et al. [2012] model does significantly better than models involving only a sill source in producing positive Coulomb stress increases on faults in both the East and Southwest Rift Zones during this period. We continue to find that none of the tested models produces Coulomb stress changes on Nāmakanipaio-area faults, again indicating that a different source of stress is required to explain this cluster of seismic activity.

\section{New geodetic analysis}

Of the existing geodetic models, the model presented in Poland et al., [2012] is 
most consistent with detailed observations of VT seismicity in Periods 1 and 2, suggesting that a reservoir in the SC is active during both periods. However, Poland et al. [2012] do not take into account the temporal variability in deformation rate by investigating Periods 1 and 2 separately, nor do they account for the majority of the observed faulting in the SWRZ in Period 2. We therefore use geodetic (InSAR + GPS) datasets, which correspond to time spans strictly included in Periods 1 and 2, to investigate the temporal variability of geodetic and seismic sources at Kîlauea in 2006.

To better reconcile geodetic models with the SWRZ seismicity and to compare our results with previous studies, we tested simple analytical sources for each period, including point-source [Mogi, 1958], spherical [McTigue, 1987], and spheroidal [Yang et al., 1988] sources to represent inflating magma reservoirs, as well as circular [Fialko et al., 2001] and rectangular [Okada, 1985] planar sources to approximate inflating sills. In all of our models, the shear modulus is $20 \mathrm{GPa}$ and Poisson's ratio is 0.25 , following the values used in Dieterich et al. [2003].

The analytical solutions are used as forward models in a near-neighborhood inversion algorithm [Sambridge, 1999a, 1999b]. We circularly subsampled all InSAR datasets with an average distance between points of 200 meters in the SC and upper SWRZ areas where displacements are large, and coarser farther away. InSAR datasets considered for Period 1 and 2 are jointly inverted with GPS data which match the start and end dates of the corresponding InSAR dataset. For all inversions, correlation distance and noise variance of the InSAR data are fixed to values of $300 \mathrm{~m}$ and $1 \times 10^{-4} \mathrm{~m}^{2}$, respectively [Fukushima et al., 2005, 2010; Fukushima, 2006; Wauthier et al., 2012, 2013]. Finally, in all inversions, the variance of the GPS data is decreased by a factor 
1000 to allow the GPS data points to weight as much as the corresponding InSAR subsampled points. Note that we tested the inversion behavior using different variance values and found that it did not change significantly the best-fit models. Using a value of 1000 was found to be a good compromise with the inversions converging toward a visually reasonable fit for both datasets.

For Period 1, we simultaneously inverted ENVISAT IS2 InSAR data and GPS data spanning Period 1 (Figure 6). Due to the large number of images available (Table S1), the descending ENVISAT IS2 data were processed using the "StaMPS" ('Stanford Method for Permanent Scatterers') technique [Hooper, 2008]. This multi-temporal approach allows us to mitigate topographic and atmospheric effects. The best-fit model for Period 1 includes an inflating spherical reservoir at a depth of $3 \mathrm{~km}$ with a volume increase of $\sim 4 \times 10^{6} \mathrm{~m}^{3}$. The location of this source is consistent with the SC reservoir modeled by Poland et al. [2012]. We find no geodetic evidence for sill intrusion in the SWRZ during Period 1.

For Period 2, we simultaneously inverted two InSAR datasets that are nearly coincident in time and included in Period 2: ENVISAT IS3 (6 May - 30 September 2006) and ALOS-1 (6 May - 6 October 2006), as well as GPS data (Figure 7). Note that we used conventional interferograms since not enough data were available to apply a multitemporal approach. The best-fit model for this subset of Period 2 (Table 2) includes the same spherical magma reservoir as for Period 1 (its location was fixed to that determined in our Period 1 model but the volume change was allowed to vary), as well as an inflating rectangular horizontal sill whose geometry and amount of opening were allowed to vary. The model sill is $1 \mathrm{~km}$ wide and $8 \mathrm{~km}$ long, and it is located $3 \mathrm{~km}$ beneath the SWRZ. 
The SC reservoir and the sill experienced volume increases of $\sim 3 \times 10^{6} \mathrm{~m}^{3}$ and $\sim 6 \times 10^{6}$ $\mathrm{m}^{3}$ (uniform opening of $\sim 0.8 \mathrm{~m}$ ), respectively. Although a sill source produces the smallest misfit to the data, significant residuals (observed - modeled, Figure 7) remain in the SWRZ.

\section{Coulomb stress modeling of new geodetic sources}

Coulomb stress analysis of the new Period 1 and Period 2 models presented in Figure 8 demonstrates that they are more consistent with observation of seismic activity in the SWRZ than previously published geodetic models. The new inflating reservoir modeled for Period 1 (Figure 6) results in a Coulomb stress increase of $>1$ bar for $92 \%$ of ERZ earthquakes and 77\% of SWRZ earthquakes (Figure 8), compared to 64\% of SWRZ earthquakes for the Poland et al. [2012] model. The inflating reservoir and sill modeled for Period 2 (Figure 7) results in a Coulomb stress increase of $>1$ bar for $82 \%$ of ERZ earthquakes and 65\% of SWRZ earthquakes (Figure 8) -a significant improvement over the Poland et al. [2012] sill+reservoir model (44\% of SWRZ earthquakes). Similar to the sill-only models of Myer et al., [2008] and Baker and Amelung [2012], we find that a sill alone results in negative Coulomb stress changes for the majority of SWRZ earthquakes. As with the previously-published models, faults in the Nāmakanipaio area appear to be unaffected by inflation of the newly-modeled sill and reservoir.

\section{Discussion}


Combined geodetic-seismic analysis not only constrains non-unique geodetic models but elucidates the processes driving VT seismicity as well. VT earthquakes may be the result of dike propagation or inflation of magma reservoirs: Hill [1977] proposed a conceptual model for the generation of earthquake swarms in volcanic environments, in which VT earthquakes occur on shear planes connecting the edges of offset (en echelon) dikes. Ukawa and Tsukahara [1996] proposed that VT earthquakes occur in a zone of inflation-induced tension ahead of the tip of a propagating dike. In both Hill's [1977] and Ukawa and Tsukahara's [1996] model, magma and VT earthquakes are in close spatial proximity to each other, and earthquake hypocenters may propagate laterally or vertically through time. Roman and Cashman [2006] demonstrated that VTs may instead occur as the result of stress transfer from proximal or distal pressurizing magma reservoirs onto optimally-oriented faults, and that the exact driving process(es) of VT seismicity may be determined through careful analysis of hypocenter locations and FPS orientations. Numerous published studies of VT seismicity in the ERZ have argued, on the basis of earthquake locations and FPS orientations, for close spatial proximity between earthquake hypocenters and magma feeding into the ERZ (e.g., [Hill, 1977; Karpin and Thurber, 1987; Gillard et al., 1996; Rubin et al., 1998), consistent with the models of Hill [1977] or Ukawa and Tsukahara [1996]. Recent geodetic (GPS and tilt) investigations [Montgomery-Brown et al., 2011] confirm that VT seismicity in the ERZ is co-located with magma intruded into a pair of en-echelon dike segments, and ERZ seismic swarm hypocenters are occasionally observed to propagate (e.g., [Rubin et al., 1998]), providing strong support for the idea that the observed strike-slip faulting in the ERZ is driven by concentrations of stresses at the tips of vertical dike segments. 
However, our Coulomb stress analysis indicates that stresses from a distal reservoir (the $\mathrm{SC}$ reservoir) may also contribute to driving ERZ seismicity. Thus, several processes may independently but constructively drive faulting in the ERZ. Due to the relatively low levels of VT seismicity in the SWRZ, the processes driving VT seismicity in this region of Kîlauea have not been well studied. There is some evidence for en echelon diking in the SWRZ during the 1974 eruption [Hill, 1977] and hypocenter migration during the January 20, 1981 SWRZ intrusion [Karpin and Thurber, 1987], suggesting that faulting processes similar to those now occurring in the ERZ drove pre-1983 episodes of SWRZ seismicity. However, the current absence of any evidence for vertical diking or hypocenter migration in the SWRZ suggests that recent SWRZ seismicity is driven by a fundamentally different process than ERZ seismicity, namely, stress transfer from an inflating distal reservoir (the SC reservoir) onto optimally-oriented SWRZ faults.

Recognition that heightened seismic activity at a volcano represents a so-called "distal VT" swarm (see below) is important for volcano monitoring in volcanoes with complex plumbing systems. For instance, our work demonstrates that a seismic swarm on the SWRZ is not necessarily an indication of magma intrusion in the SWRZ, and thus is not necessarily an indication of heightened probability of a SWRZ eruption. However, previous studies highlight the difficulty in defining the term "distal VT" and the method of classification of a swarm as "distal VT". For example, White and McCausland [2016] define distal VT seismicity as "VT seismicity originating at foci well away from the eventual eruption vent at lateral distances ranging from one or two to more than $30 \mathrm{~km} . "$ There are several potential issues with this definition. First, it includes purely tectonic earthquake swarms (e.g., [Vidale and Shearer, 2006]) if they happen to occur in vaguely- 
defined spatiotemporal proximity to an erupting volcano. Second, it excludes noneruptive swarms driven by distal magmatic activity (e.g., [Lu et al., 2000; White and McCausland, 2016] discuss 'distal VT' seismicity during apparent magmatic intrusions despite excluding these cases in their definition). Our results suggest a more functional definition of distal VT seismicity as earthquakes that are physically distant from the magma body that is the source of their driving stress. On the basis of this definition, a distal VT swarm can objectively be identified through Coulomb stress modeling of VT FPS and a known (e.g., from geodetic modeling) or assumed (e.g., from vent location) source.

A second major implication of our results is that, while magma was intruding in the SWRZ in 2006, this intrusion was largely aseismic, despite there being seismic activity in the SWRZ. We propose two (nonexclusive) explanations for aseismic SWRZ inflation in 2006. The first is that the faults in the SWRZ are not optimally oriented to respond to the primarily vertical stresses induced by sill inflation. The second is that the rate of magma intrusion was too low to produce strain rates high enough to drive measurable seismicity (e.g., [Toda et al., 2002; Roman and Gardine, 2013]).

For the inflation period in 2006 at Kîlauea Volcano, we suggest that overpressurized magma was supplied to the SC reservoir during Period 1 and that, during Period 2, the amount of overpressurized magma began to intrude into the SWRZ reservoir to release excess pressure in the SC reservoir. Thus, the SWRZ might act as an "overflow" mushy reservoir being fed from the SC main reservoir when magma storage rates increase dramatically, such as during the 2003-2007 magma surge [Poland et al., 2012; Anderson and Poland, 2016]. Inflation signals observed in the SWRZ would be the 
consequence of the input of magma into a pre-existing reservoir beneath the SWRZ. Regions of high seismic velocity and dense zones detected by gravity beneath the caldera and upper portions of both rift zones have been interpreted as cumulates capable of ductile flow [Clague and Denlinger, 1994]. To test this hypothesis, better fit the geodetic data in the SWRZ and thus better understand and model magma processes occurring beneath the SWRZ, more complex modeling approaches (e.g., FEMs [Masterlark et al., 2012]) are required.

Many volcanoes are a complex assemblage of magma storage and transport regions and faults, which interact through stress transfer in the host rock surrounding the system. As we have demonstrated, careful observations of temporal variations in surface deformation and fault slip may be linked together through Coulomb stress change modeling of stress sources consistent with both sets of observations, leading to a clearer and better-constrained picture of the dynamics of magma movement in a volcano's plumbing system. A growing number of volcanoes have seismic networks sufficient for fault-plane solution analysis. While VT FPS are influenced by pre-existing fault locations and orientations, when analyzed in detail they have proven to be reliable indicators of stress changes due to magmatic processes (e.g., [Arámbula-Mendoza et al., 2010; Massin et al., 2011; Lehto et al., 2013]). The growing recognition that many active volcanoes host VT swarms resulting from stress increases in a distal magma chamber ('distal VT swarms', [Roman et al., 2008; White and McCausland, 2016]) indicates that there is significant potential for using Coulomb stress analysis of FPS to discriminate between different analytical geodetic models for magma bodies, particularly in cases where there is geodetic evidence for multiple or complex deformation sources (e.g., [Foroozan et al., 
2010; Bagnardi and Amelung, 2012; Wauthier et al., 2012]). Ultimately, this information is critical for improved forecasting of the timing and location of changes in a volcano's behavior.

\section{Acknowledgements}

The interferograms were processed using ROI-PAC [Rosen et al., 2004], StaMPS [Hooper, 2008] and unwrapped with SNAPHU [Chen and Zebker, 2001]. The authors would acknowledge the use of the MATLAB toolbox DMODELS [Battaglia et al., 2013] and Coulomb 3.3 [Lin, 2004; Toda et al., 2005]. Thank you to the staff of the U.S. Geological Survey (USGS) Hawaiian Volcano Observatory for providing data and feedback for this work, in particular Asta Miklius and Wes Thelen. The GPS network is operated in collaboration by the USGS, Stanford University, and Pacific GPS Facility at the University of Hawai' $i$. The GPS, seismic and SAR data are available from UNAVCO, IRIS and the Hawaii Supersite and the European Space Agency, respectively. The authors thank Andy Hooper for his help with the use of StaMPS. Finally, the authors are grateful to the associate editor Peter Shearer, Paul Lundgren, Ingrid Johansson, Daniel Dzurisin and an anonymous reviewer for their reviews and comments which greatly helped improve the manuscript. Any use of trade, firm, or product names is for descriptive purposes only and does not imply endorsement by the U.S. Government.

\section{References}

Anderson, K. R., and M. P. Poland (2016), Bayesian estimation of magma supply, storage, and eruption rates using a multiphysical volcano model: Kīlauea Volcano, 
2000-2012, Earth Planet. Sci. Lett., 447, 161-171, doi:10.1016/j.eps1.2016.04.029.

Arámbula-Mendoza, R., C. Valdés-González, and A. Martínez-Bringas (2010), Temporal and spatial variation of the stress state of Popocatépetl Volcano, Mexico, $J$.

Volcanol. Geotherm. Res., 196(3), 156-168, doi:10.1016/j.jvolgeores.2010.07.007.

Bagnardi, M., and F. Amelung (2012), Space-geodetic evidence for multiple magma reservoirs and subvolcanic lateral intrusions at Fernandina Volcano, Galápagos Islands, J. Geophys. Res. Solid Earth, 117(B10), n/a-n/a, doi:10.1029/2012JB009465.

Bagnardi, M., M. P. Poland, D. Carbone, S. Baker, M. Battaglia, and F. Amelung (2014), Journal of Geophysical Research : Solid Earth, J. Geophys. Res. Solid Earth, 72887305, doi:10.1002/2014JB011506.Received.

Baker, S., and F. Amelung (2012), Top-down inflation and deflation at the summit of Klauea Volcano, Hawaii observed with InSAR, J. Geophys. Res. Solid Earth, 117(12), 1-14, doi:10.1029/2011JB009123.

Battaglia, M., P. F. Cervelli, and J. R. Murray (2013), DMODELS: A MATLAB software package for modeling crustal deformation near active faults and volcanic centers, $J$. Volcanol. Geotherm. Res., 254, 1-4, doi:10.1016/j.jvolgeores.2012.12.018.

Bonaccorso, a. (2002), Dike emplacement forerunning the Etna July 2001 eruption modeled through continuous tilt and GPS data, Geophys. Res. Lett., 29(13), 13-16, doi:10.1029/2001GL014397.

Bonforte, A., A. Bonaccorso, F. Guglielmino, M. Palano, and G. Puglisi (2008), Feeding system and magma storage beneath Mt. Etna as revealed by recent inflation/deflation cycles, J. Geophys. Res., 113(B5), B05406, 
doi:10.1029/2007JB005334.

Cervelli, P. F., and A. Miklius (2003), The Shallow Magmatic System of Kilauea Volcano, Pu`u 'O`o--Kupaianaha Erupt. Kilauea Volcano, Hawai`i First 20 Years, $149-164$.

Chen, C. W., and H. a. Zebker (2001), Two-dimensional phase unwrapping with use of statistical models for cost functions in nonlinear optimization, J. Opt. Soc. Am. A, 18(2), 338, doi:10.1364/JOSAA.18.000338.

Clague, D. A., and R. P. Denlinger (1994), Role of olivine cumulates in destabilizing the flanks of Hawaiian volcanoes, Bull. Volcanol., 56(6-7), 425-434, doi:10.1007/BF00302824.

Dieterich, J. H., V. Cayol, and P. Okubo (2003), Stress changes before and during the Pu'u “O”o-Kupaianaha eruption, USGS Prof. Pap., 1676, 187-202.

Dvorak, J. J., and D. Dzurisin (1997), Volcano geodesy: The search for magma reservoirs and the formation of eruptive vents, Rev. Geophys., 35(3), 343, doi:10.1029/97RG00070.

Dzurisin, D. (2006), Volcano Deformation, Springer Berlin Heidelberg, Berlin, Heidelberg.

Fialko, Y., Y. Khazan, and M. Simons (2001), Deformation due to a pressurized horizontal circular crack in an elastic half-space, with applications to volcano geodesy, Geophys. J. Int., 146(1), 181-190, doi:10.1046/j.1365-246X.2001.00452.x.

Foroozan, R., D. Elsworth, B. Voight, and G. S. Mattioli (2010), Dual reservoir structure at Soufrière Hills Volcano inferred from continuous GPS observations and heterogeneous elastic modeling, Geophys. Res. Lett., 37(19), n/a-n/a, 
doi:10.1029/2010GL042511.

Fukushima, Y. (2006), Transferts de magma au volcan du piton de la fournaise determines par la modelisation 3d de donnees d'interferometrie radar entre 1998 et 2000, Universite Blaise-Pascal.

Fukushima, Y., V. Cayol, and P. Durand (2005), Finding realistic dike models from interferometric synthetic aperture radar data: The February 2000 eruption at Piton de la Fournaise, J. Geophys. Res., 110(B3), B03206, doi:10.1029/2004JB003268.

Fukushima, Y., V. Cayol, P. Durand, and D. Massonnet (2010), Evolution of magma conduits during the 1998-2000 eruptions of Piton de la Fournaise volcano, Réunion Island, J. Geophys. Res. Solid Earth, 115(March), 1-21, doi:10.1029/2009JB007023.

Giampiccolo, E., C. Musumeci, S. D. Malone, S. Gresta, and E. Privitera (1999), Seismicity and stress-tensor inversion in the central Washington Cascade Mountains, Bull. Seismol. Soc. Am. , 89(3), 811-821.

Gillard, D., M. Wyss, and P. Okubo (1996), Type of faulting and orientation of stress and strain as a function of space and time in Kilauea's south flank, Hawaii, J. Geophys. Res., 101(B7), 16025-16042, doi:10.1029/96JB00651.

Hill, D. P. (1977), A model for earthquake swarms, J. Geophys. Res., 82(8), 1347, doi:10.1029/JB082i008p01347.

Hooper, A. J. (2008), A multi-temporal InSAR method incorporating both persistent scatterer and small baseline approaches, Geophys. Res. Lett., 35(16), 1-5, doi:10.1029/2008GL034654.

Johnson, J. H., D. A. Swanson, D. C. Roman, M. P. Poland, and W. A. Thelen (2015), 
Crustal stress and structure at Kilauea Volcano inferred from seismic anisotropy., in Hawaiian Volcanoes: From Source to Surface, Geophysical Monograph, vol. 208, edited by R. J. Carey, V. Cayol, M. P. Poland, and D. Weis, pp. 251-268.

Jolly, A. D., R. A. Page, and J. A. Power (1994), Seismicity and stress in the vicinity of Mount-Spurr Volcano, south central Alaska, J. Geophys. Res., 99(B8), 1530515318, doi:10.1029/94JB00136.

Karpin, T. L., and C. H. Thurber (1987), The relationship between earthquake swarms and magma transport: Kilauea volcano, Hawaii, Pure Appl. Geophys. PAGEOPH, 125(6), 971-991, doi:10.1007/BF00879363.

Lehto, H. L., D. C. Roman, and S. C. Moran (2013), Source mechanisms of persistent shallow earthquakes during eruptive and non-eruptive periods between 1981 and 2011 at Mount St. Helens, Washington, J. Volcanol. Geotherm. Res., 256, 1-15, doi:10.1016/j.jvolgeores.2013.02.005.

Lin, J. (2004), Stress triggering in thrust and subduction earthquakes and stress interaction between the southern San Andreas and nearby thrust and strike-slip faults, J. Geophys. Res., 109(B2), 1-19, doi:10.1029/2003JB002607.

Lu, Z., C. Wicks, J. A. Power, and D. Dzurisin (2000), Ground deformation associated with the March 1996 earthquake swarm at Akutan volcano, Alaska, revealed by satellite radar interferometry, J. Geophys. Res. Solid Earth, 105(B9), 21483-21495, doi:10.1029/2000JB900200.

Lundgren, P., and P. A. Rosen (2003), Source model for the 2001 flank eruption of Mt. Etna volcano, Geophys. Res. Lett., 30(7), 1388, doi:10.1029/2002GL016774. Massin, F., V. Ferrazzini, P. Bachèlery, A. Nercessian, Z. Duputel, and T. Staudacher 
(2011), Structures and evolution of the plumbing system of Piton de la Fournaise volcano inferred from clustering of 2007 eruptive cycle seismicity, J. Volcanol. Geotherm. Res., 202(1), 96-106, doi:10.1016/j.jvolgeores.2011.01.008.

Masterlark, T., K. L. Feigl, M. Haney, J. Stone, C. Thurber, and E. Ronchin (2012), Nonlinear estimation of geometric parameters in FEMs of volcano deformation: Integrating tomography models and geodetic data for Okmok volcano, Alaska, $J$. Geophys. Res. Solid Earth, 117(2), 1-17, doi:10.1029/2011JB008811.

Matoza, R. S., P. M. Shearer, G. Lin, C. J. Wolfe, and P. G. Okubo (2013), Systematic relocation of seismicity on Hawaii Island from 1992 to 2009 using waveform cross correlation and cluster analysis, J. Geophys. Res. Solid Earth, 118(5), 2275-2288, doi:10.1002/jgrb.50189.

McTigue, D. F. (1987), Elastic stress and deformation near a finite spherical magma body: Resolution of the point source paradox, J. Geophys. Res., 92(B12), 1293112940, doi:10.1029/JB092iB12p12931.

Mogi, K. (1958), Relations between the eruptions of various volcanoes and the deformations of the ground surfaces around them, Bull. Earthq. Res. Inst., 36, 99134, doi:10.1016/j.epsl.2004.04.016.

Montgomery-Brown, E. K., D. K. Sinnett, M. Poland, P. Segall, T. Orr, H. Zebker, and a. Miklius (2010), Geodetic evidence for en echelon dike emplacement and concurrent slow slip during the June 2007 intrusion and eruption at Klauea volcano, Hawaii, J. Geophys. Res. Solid Earth, 115(7), 1-15, doi:10.1029/2009JB006658.

Montgomery-Brown, E. K., D. K. Sinnett, K. M. Larson, M. P. Poland, P. Segall, and A. Miklius (2011), Spatiotemporal evolution of dike opening and décollement slip at 
Kīlauea Volcano, Hawai'i, J. Geophys. Res., 116(B3), B03401, doi:10.1029/2010JB007762.

Myer, D., D. Sandwell, and B. Brooks (2008), Inflation along Kilauea's southwest rift zone in 2006, J. Volcanol. Geotherm. Res., 177(2), 418-424, doi:10.1016/j.jvolgeores.2008.06.006.

Nakata, J. S., and P. G. Okubo (2008), Hawaiian Volcano Observatory Seismic Data, January to December 2007, U.S. Geol. Surv. Open-File Rep., 1261.

Okada, Y. (1985), Surface deformation due to shear and tensile faults in a half-space, Bull. Seismol. Soc. Am., 75(4), 1135-1154, doi:10.1016/0148-9062(86)90674-1.

Pietruszka, A. J., and M. O. Garcia (1999), The size and shape of Kilauea Volcano’s summit magma storage reservoir: A geochemical probe, Earth Planet. Sci. Lett., 167(3-4), 311-320, doi:10.1016/S0012-821X(99)00036-9.

Poland, B. M. P., A. Miklius, and E. K. Montgomery-brown (2014), Magma Supply, Storage, and Transport at Shield-Stage Hawaiian Volcanoes, U.S. Geol. Surv. Prof. Pap., Not Publis, 1-52, doi:10.3133/pp1801.

Poland, M., A. Miklius, and T. Orr (2008), New episodes of volcanism at Kilauea Volcano, Hawaii, Eos, Trans. ..., 89(5), 37-38, doi:10.1029/2008EO050001.

Poland, M. P., A. Miklius, A. Jeff Sutton, and C. R. Thornber (2012), A mantle-driven surge in magma supply to Kīlauea Volcano during 2003-2007, Nat. Geosci., 5(4), 295-300, doi:10.1038/ngeo1426.

Reasenberg, P., and D. H. Oppenheimer (1985), FPFIT, FPPLOT and FPPAGE; Fortran computer programs for calculating and displaying earthquake fault-plane solutions, RPRT. 
Roman, D. C., and K. V. Cashman (2006), The origin of volcano-tectonic earthquake swarms, Geology, 34(6), 457, doi:10.1130/G22269.1.

Roman, D. C., and M. D. Gardine (2013), Seismological evidence for long-term and rapidly accelerating magma pressurization preceding the 2009 eruption of Redoubt Volcano, Alaska.

Roman, D. C., S. De Angelis, J. L. Latchman, and R. White (2008), Patterns of volcanotectonic seismicity and stress during the ongoing eruption of the Soufrière Hills Volcano, Montserrat (1995-2007), J. Volcanol. Geotherm. Res., 173(3), 230244, doi:10.1016/j.jvolgeores.2008.01.014.

Rosen, P. a., S. Hensley, G. Peltzer, and M. Simons (2004), Updated repeat orbit interferometry package released, Eos, Trans. Am. Geophys. Union, 85(5), 47, doi:10.1029/2004EO050004.

Rubin, A. M., D. Gillard, and J.-L. Got (1998), A reinterpretation of seismicity associated with the January 1983 dike intrusion at Kilauea Volcano, Hawaii, J. Geophys. Res., 103(B5), 10003, doi:10.1029/97JB03513.

Sambridge, M. (1999a), Geophysical inversion with a neighbourhood algorithm-II. Appraising the ensemble, Geophys. J. Int., 138(3), 727-746, doi:10.1046/j.1365246x.1999.00900.x.

Sambridge, M. (1999b), Geophysical inversion with a neighbourhood algorithm - I. Searching a parameter space, Geophys. J. Int., 138(2), 479-494, doi:10.1046/j.1365246X.1999.00876.x.

Segall, P. (2010), Earthquake and Volcano Deformation.

Segall, P. (2013), Volcano deformation and eruption forecasting, Geol. Soc. London, 
Spec. Publ., 380(1), 85-106, doi:10.1144/SP380.4.

Segall, P., and S.-H. Yun (2005), Imaging dike intrusion by joint inversion of deformation and seismicity, in American Geophysical Union, Fall Meeting 2005.

Segall, P., A. L. Llenos, S. H. Yun, A. M. Bradley, and E. M. Syracuse (2013), Timedependent dike propagation from joint inversion of seismicity and deformation data, J. Geophys. Res. Solid Earth, 118(11), 5785-5804, doi:10.1002/2013JB010251.

Tilling, R. I., and J. J. Dvorak (1993), Anatomy of a basaltic volcano, Nature, 363, 125133, doi:10.1038/363125a0.

Toda, S., R. S. Stein, and T. Sagiya (2002), Evidence from the AD 2000 Izu islands earthquake swarm that stressing rate governs seismicity., Nature, 419(6902), 58-61, doi:10.1038/nature00997.

Toda, S., R. S. Stein, K. Richards-Dinger, and S. B. Bozkurt (2005), Forecasting the evolution of seismicity in southern California: Animations built on earthquake stress transfer, J. Geophys. Res. B Solid Earth, 110(5), 1-17, doi:10.1029/2004JB003415.

Ukawa, M., and H. Tsukahara (1996), Earthquake swarms and dike intrusions off the east coast of Izu Peninsula, central Japan, Tectonophysics, 253(3-4), 285-303, doi:10.1016/0040-1951(95)00077-1.

Vidale, J. E., and P. M. Shearer (2006), A survey of 71 earthquake bursts across southern California: Exploring the role of pore fluid pressure fluctuations and aseismic slip as drivers, J. Geophys. Res. Solid Earth, 111(B5), n/a-n/a, doi:10.1029/2005JB004034.

Wauthier, C., V. Cayol, F. Kervyn, and N. d'Oreye (2012), Magma sources involved in the 2002 Nyiragongo eruption, as inferred from an InSAR analysis, J. Geophys. Res., 117(B5), B05411, doi:10.1029/2011jb008257. 
Wauthier, C., V. Cayol, M. Poland, F. Kervyn, N. D’Oreye, A. Hooper, S. Samsonov, K. Tiampo, and B. Smets (2013), Nyamulagira's magma plumbing system inferred from 15 years of InSAR, Geol. Soc. London, Spec. Publ., 380(1), 39-65, doi:10.1144/SP380.9.

White, R., and W. McCausland (2016), Volcano-tectonic earthquakes: A new tool for estimating intrusive volumes and forecasting eruptions, J. Volcanol. Geotherm. Res., 309, 139-155, doi:10.1016/j.jvolgeores.2015.10.020.

Wolfe, E. W., and J. Morris (1989), Geologic map of the Island of Hawaii, Compil. by Edward W. Wolfe Jean Morris.

Wright, T. L., and F. W. Klein (2014), Two Hundred Years of Magma Transport and Storage at Kïlauea Volcano, Hawai ‘ i , 1790 - 2008 Professional Paper 1806, U.S. Geol. Surv. Prof. Pap., 1806, 1790-2008, doi:10.3133/pp1806.

Yang, X.-M., P. M. Davis, and J. H. Dieterich (1988), Deformation from inflation of a dipping finite prolate spheroid in an elastic half-space as a model for volcanic stressing, J. Geophys. Res., 93(B5), 4249, doi:10.1029/JB093iB05p04249. 


\section{Figures}

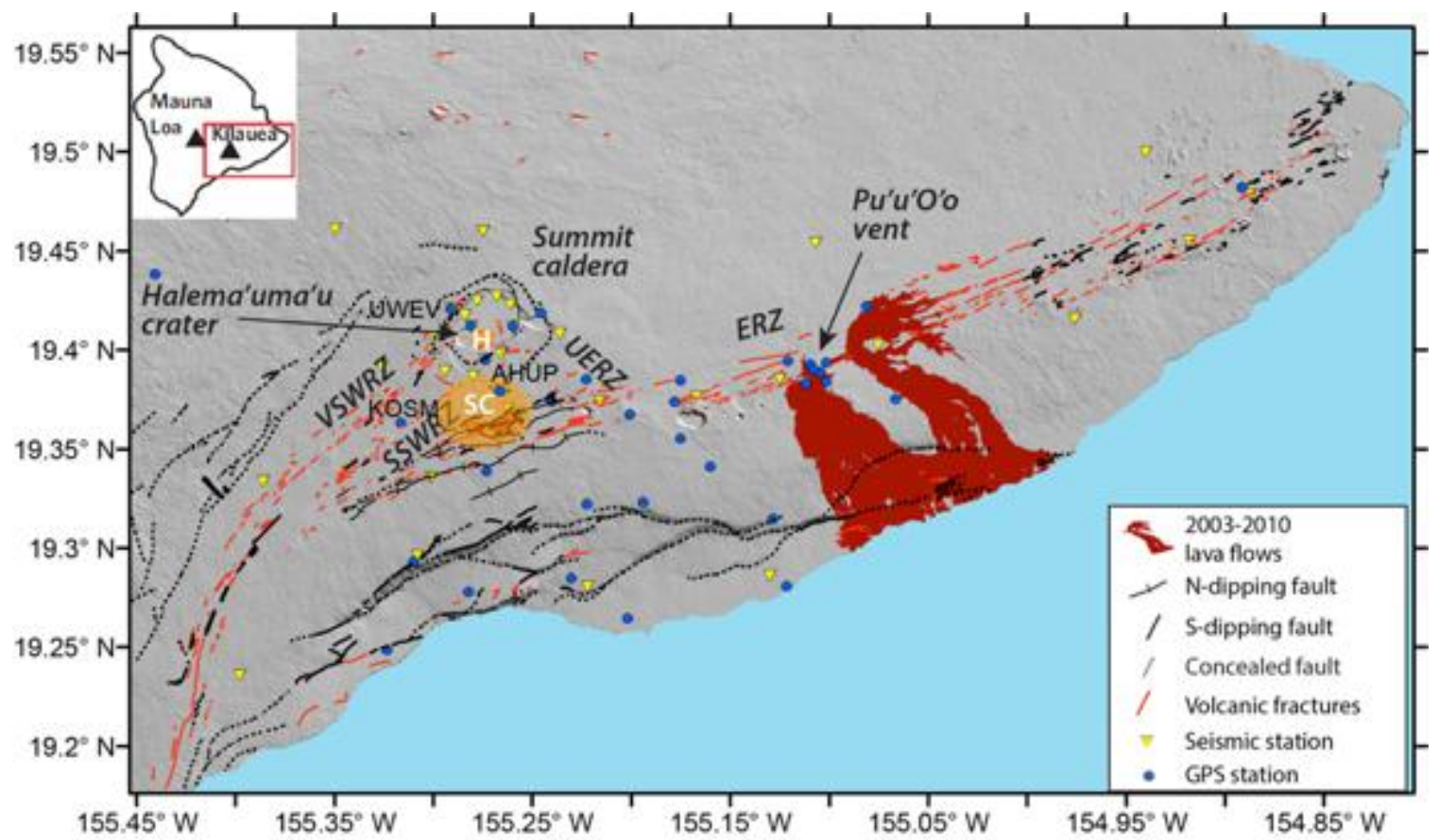

Figure 1. Geological setting of Kîlauea Volcano, Hawai'i, modified after [Wolfe and Morris, 1989]. Major craters and faults are outlined. H = Halema'uma'u reservoir, SC = south caldera reservoir, SSWRZ $=$ Seismic Southwest Rift Zone, VSWRZ = Volcanic Southwest Rift Zone, ERZ = East Rift Zone; UERZ = Upper East Rift Zone. Left-upper Inset: Location of map on the Island of Hawai' $i$, with the summits of Kilauea and Mauna Loa volcanoes indicated. 


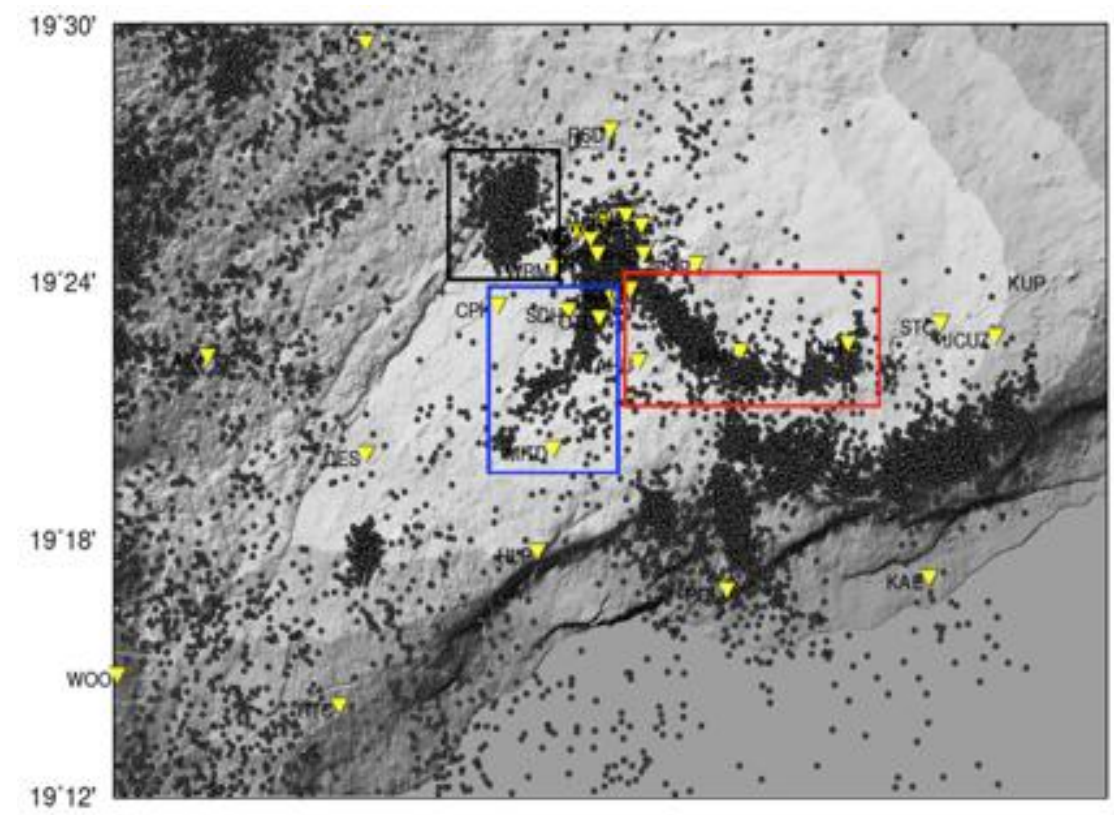

$155^{\prime} 30^{\prime}$

$155^{\prime \prime} 15^{\prime \prime}$
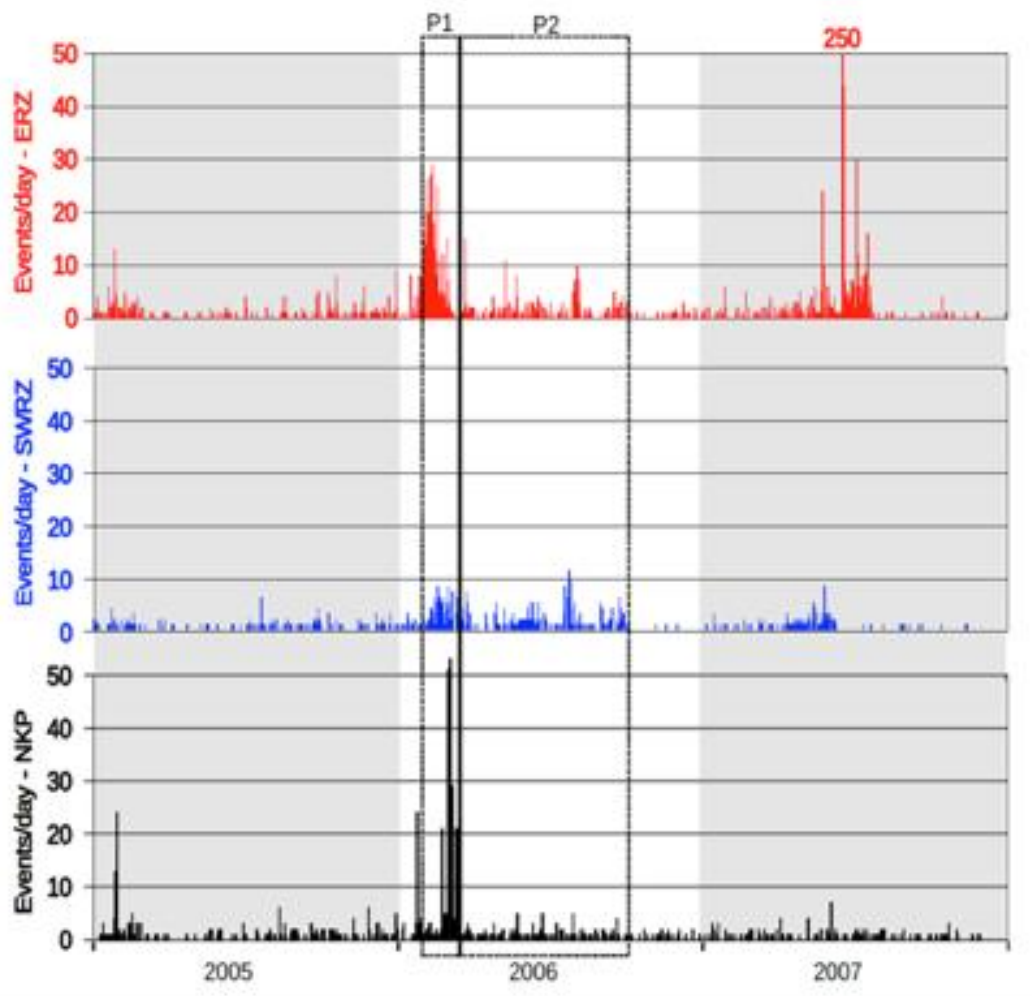

Figure 2. Seismicity of Kilauea in 2005-2007. Top panel shows epicenter locations (gray dots) of all earthquakes at Kilauea in the HVO catalog [Nakata and Okubo, 2008] for 2005-2007. Yellow triangles show the location of permanent seismic stations operated by HVO. Also shown are the locations of three areas that experienced elevated seismicity during our study period. The 
black box outlines Namakanipaio (NKP), the blue box outlines the Southwest Rift Zone (SWRZ) and the red box outlines the East Rift Zone (ERZ). Bottom three panels show the number of earthquakes per day in these three areas. Periods 1 and 2, defined in the text, are outlined by the black dashed boxes.

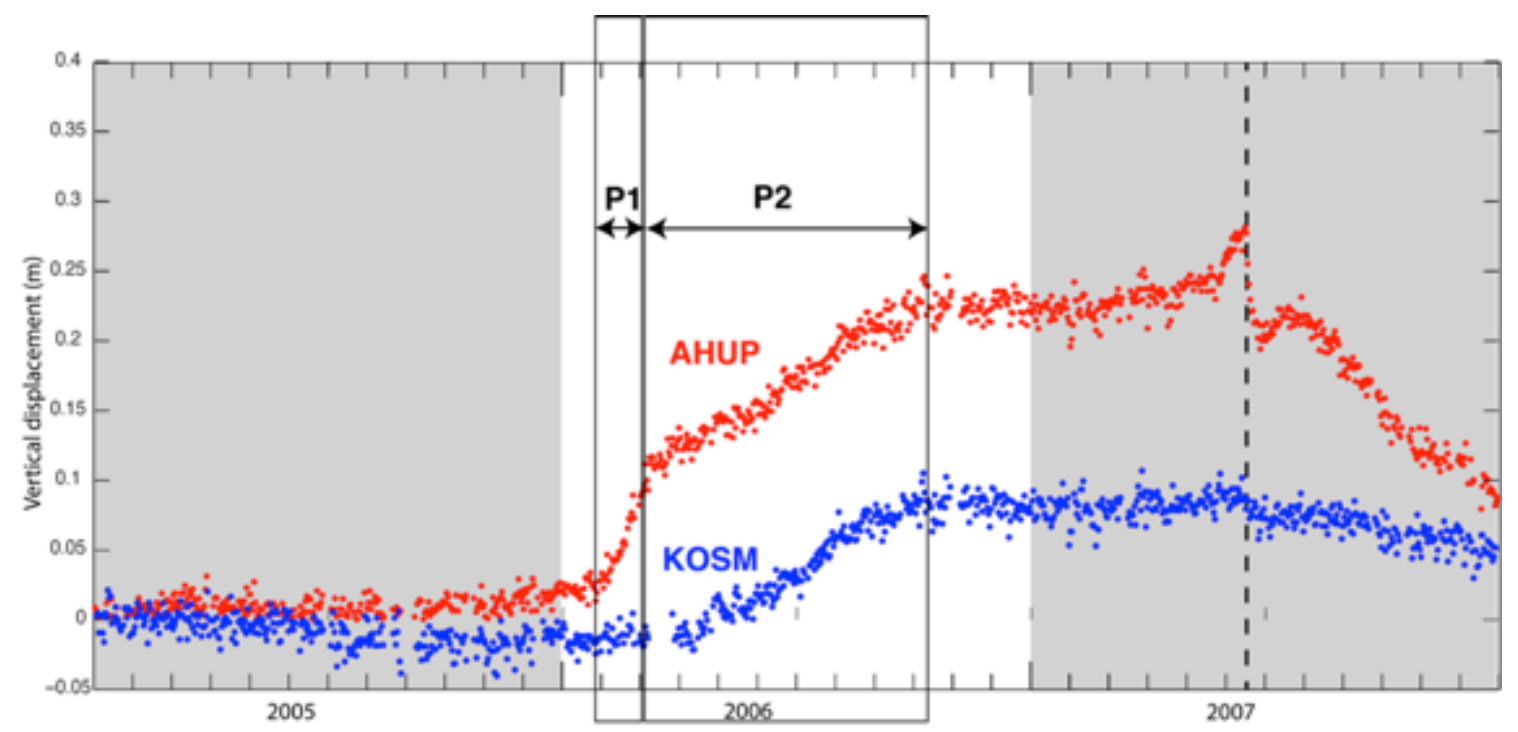

Figure 3. Geodetic data showing changes in the rate of deformation in 2005-2007 at GPS station AHUP (red) and KOSM (blue), located south and southwest of the summit of Killauea, respectively (Figure 1). Note the change in rate of inflation in March 2006, delineating Periods 1 and 2 of this study. The black arrows show the time spanned by Period 1 (P1) and Period 2 (P2). Vertical dashed line marks the date of the "Father's Day" (FD) event. 


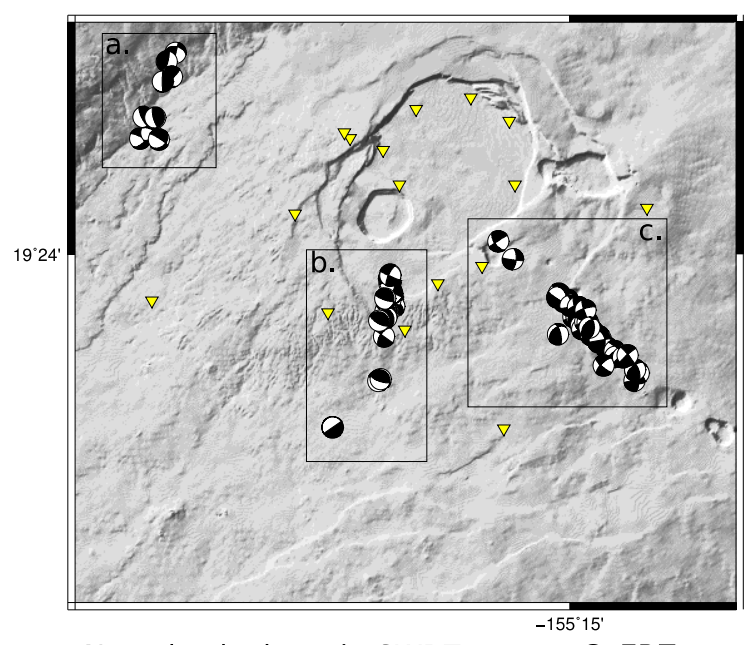

a. Namakanipaio

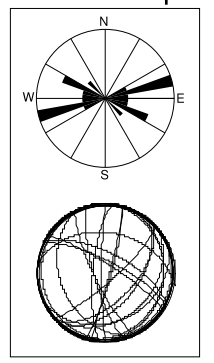

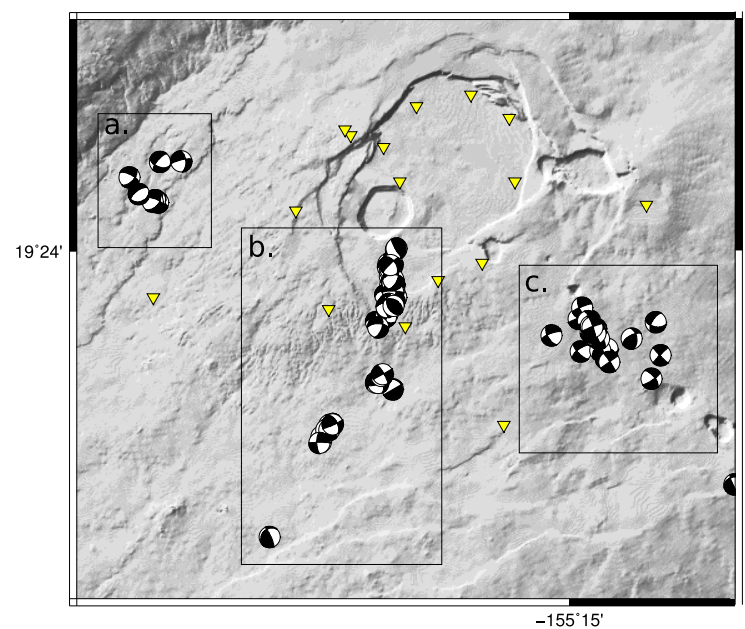

a. Namakanipaio

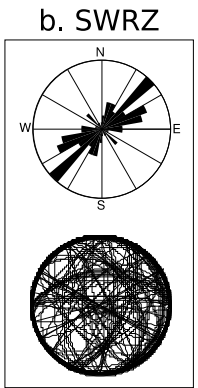

C. ERZ

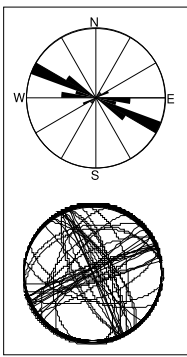

Figure 4. High-quality double-couple FPS in Period 1 (left) and 2 (right). Three areas of seismic activity are outlined with black boxes, and Rose diagrams of P-axis orientations are shown for Namakanipaio, the upper SWRZ and ERZ. 


\section{Period 1}

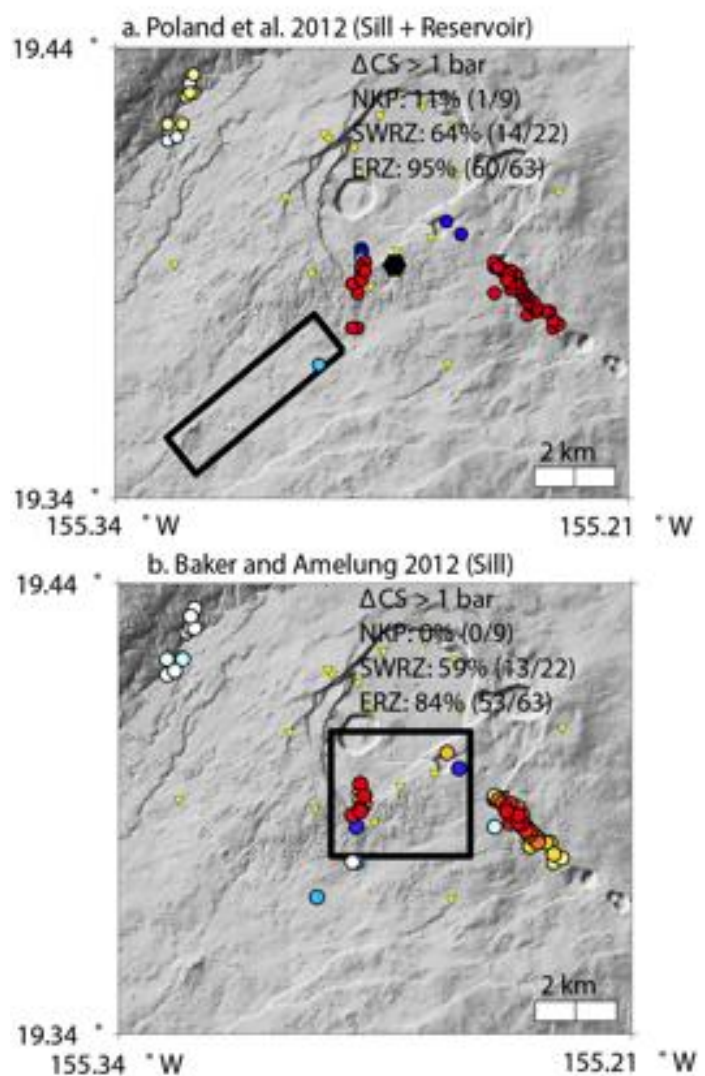

\section{Period 2}

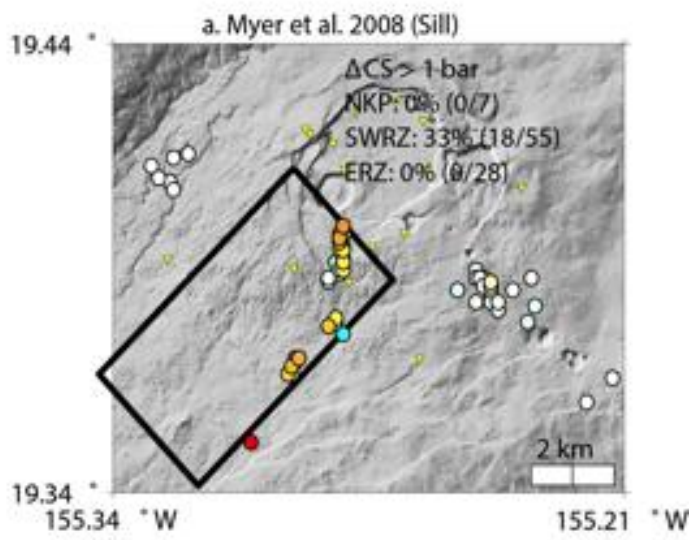

19.44 - b. Poland et al. 2012 (Sill + Reservoir)

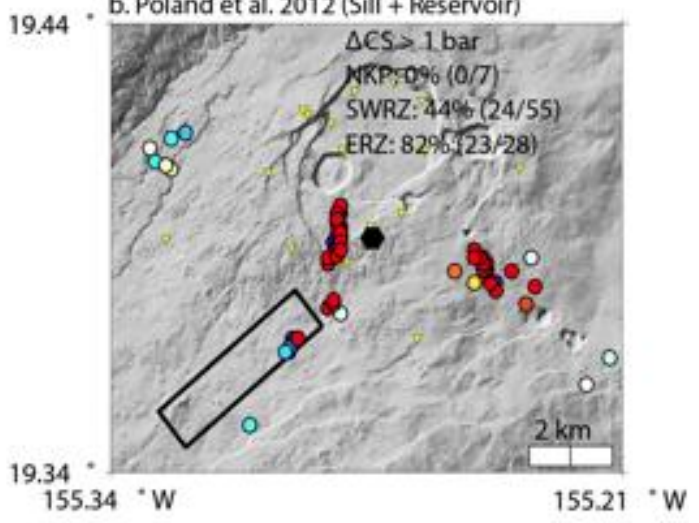

c. Baker and Amelung 2012 (Sill)

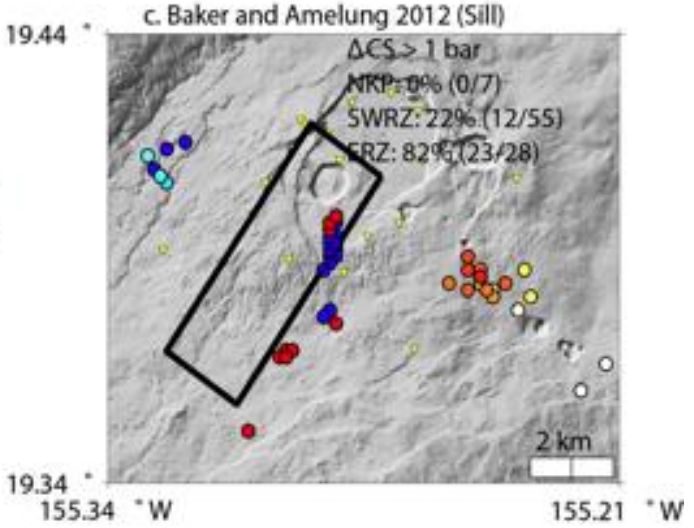

Figure 5. Coulomb stress changes induced by the published deformation sources (see

Table 1) on receiver faults corresponding to the calculated VT FPS (Figure 4). The location and extend of best-fit sources are indicated with black boxes for sills and black stars for magma reservoirs. 


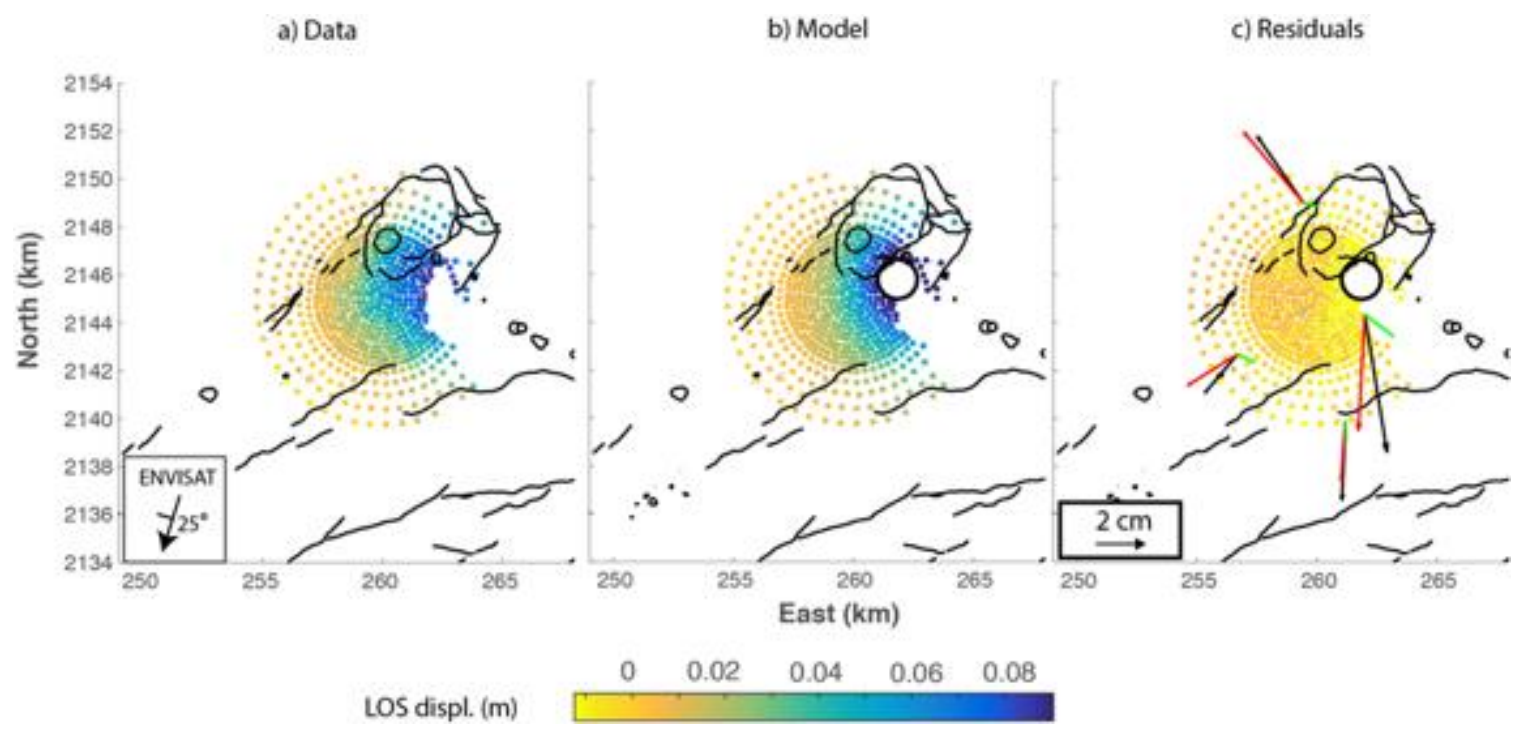

Figure 6. Data - Model - Residuals for MT-InSAR ENVISAT descending i2 (February 1

- March 15 2006) covering the entire Period 1. Observed, modeled and residual GPS displacements are shown with black, red and green arrows, respectively. Black outlined circles show the location of the best-fit magma reservoir. 


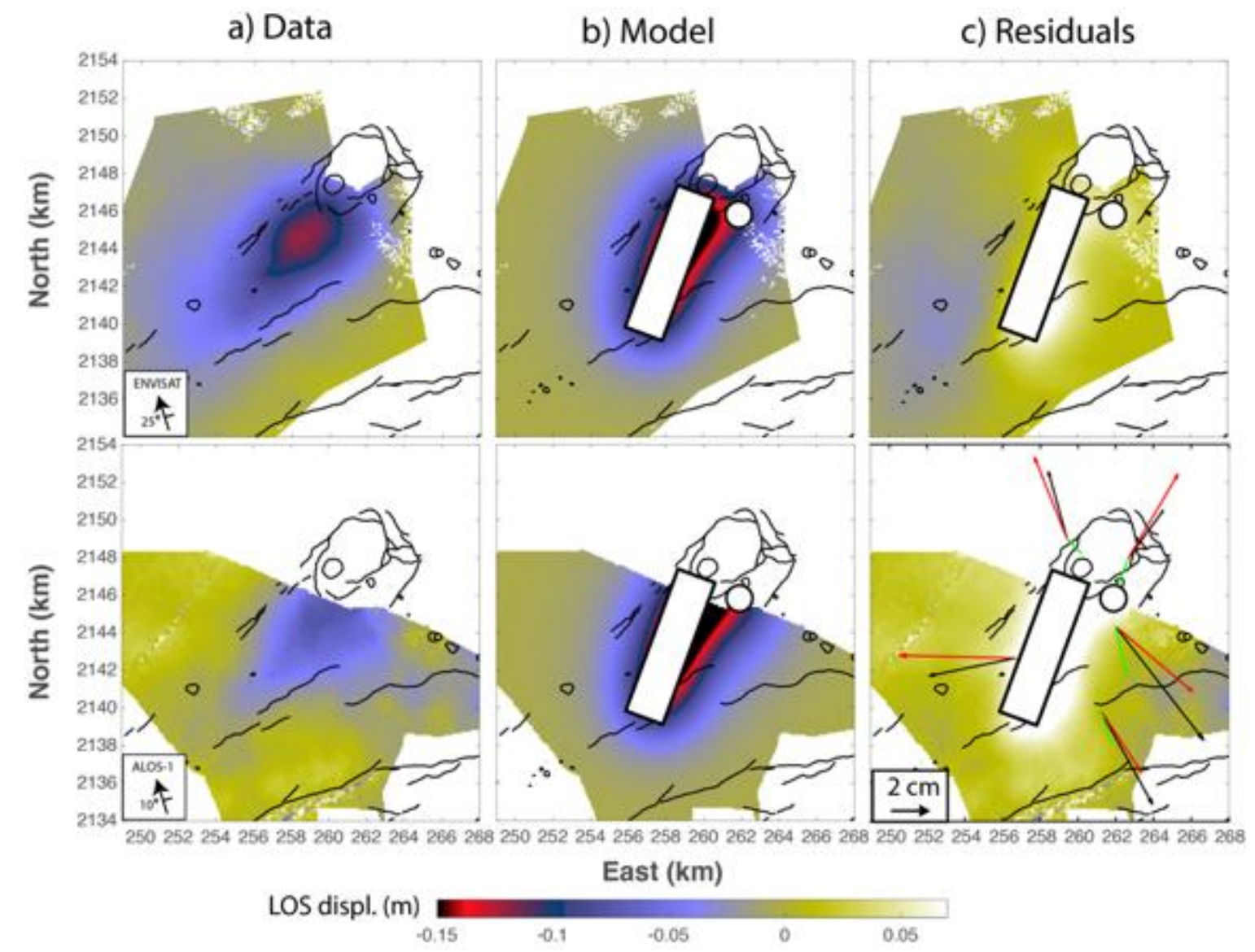

Figure 7. Data - Model - Residuals for a) ENVISAT ascending i3 (May - September 2006) and b) ALOS ascending (May - September 2006). Observed, modeled and residual GPS displacements are shown with black, red and green arrows, respectively. Black outlined circles show the location of the best-fit magma reservoir and black outlined rectangles show the location of the best-fit sill. 
a. This study - Period 1 (Reservoir)
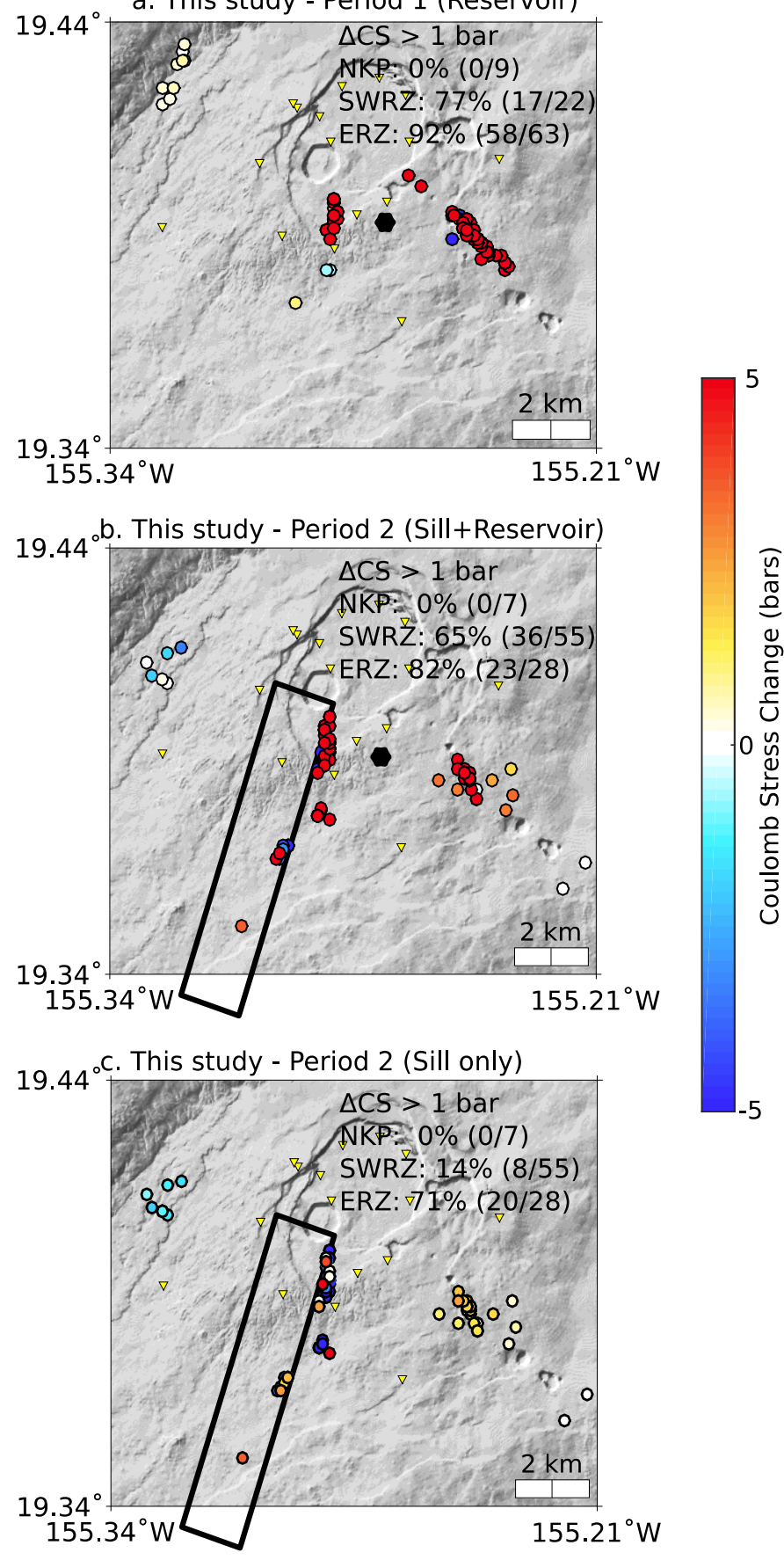

Figure 8. Coulomb stress changes induced by the deformation sources inferred in this study on receiver faults corresponding to the calculated VT FPS (Figure 4). Black hexagons show the location of the best-fit magma reservoir and black outlined rectangles show the location of the best-fit sill. 


\section{Tables}

\begin{tabular}{|c|c|c|c|c|}
\hline Study & Dates covered & Period 1 & Period 2 & Result \\
\hline Myer et al. [2008] & May - Nov. 2006 & & $\mathrm{X}$ & SWRZ sill. \\
\hline Poland et al. [2012] & Dec. 2005 - Dec. 2006 & Treated as & single period & SC point-source reservoir and SWRZ sill. \\
\hline Baker and Amelung [2012] & Feb. - Oct. 2006 & $\mathrm{X}$ & $\mathrm{X}$ & SC sill reservoir in $\mathrm{P} 1$ and $\mathrm{SWRZ}$ sill in $\mathrm{P} 2$. \\
\hline Poland et al. [2014] & May - Sept. 2006 & & $\mathrm{X}$ & SWRZ sill in P2. Some opening in SC as well. \\
\hline Anderson and Poland [2016] & Dec. 2005 - Dec. 2006 & Treated as & single period & SWRZ sill. \\
\hline
\end{tabular}

Table 1. Comparison of previous studies' results for the geodetic modeling of active deformation sources in 2006 at Kîlauea.

\begin{tabular}{|c|c|}
\hline \multicolumn{2}{|c|}{ Period 1} \\
\hline Source Type & Spherical reservoir [McTigue, 1987] \\
\hline Volume change (106 m3) & $4.1^{[3.55 .3]}$ \\
\hline Center Latitude $\left({ }^{\circ}\right)$ & $19.39^{[19.3919 .40]}$ \\
\hline Center Longitude $\left({ }^{\circ}\right.$, West $)$ & $155.27^{\lfloor 155.266155 .269\rfloor}$ \\
\hline Depth (km beneath surface) & $3^{[2.93 .1]}$ \\
\hline Radius (m) & $586^{[5556225]}$ \\
\hline RMS error $(\mathrm{cm})$ & 0.9 \\
\hline \multicolumn{2}{|c|}{ Period 2} \\
\hline \multicolumn{2}{|l|}{ Source 1} \\
\hline Source Type & Spherical reservoir [McTigue, 1987] \\
\hline Volume change (106 m3) & $2.8^{\left[2.3^{3} 3.4\right]}$ \\
\hline Center Latitude $\left(^{\circ}\right)$ & $19.39^{*}$ \\
\hline Center Longitude ( ${ }^{\circ}$, West) & $155.27^{*}$ \\
\hline Depth (km beneath surface) & $3^{*}$ \\
\hline Radius (m) & $586^{*}$ \\
\hline \multicolumn{2}{|l|}{ Source 2} \\
\hline Source Type & Sill [Okada, 1985] \\
\hline Opening (m) & $0.76^{[0.150 .18]}$ \\
\hline $\operatorname{Dip}\left({ }^{\circ}\right)$ & $0^{*}$ \\
\hline Strike $\left({ }^{\circ}\right)$ & $20^{[2021]}$ \\
\hline Length (m) & $8032^{[79908110]}$ \\
\hline Width (m) & $1050^{[10301070]}$ \\
\hline Depth (km beneath surface) & $3^{*}$ \\
\hline Center Latitude $\left(^{\circ}\right)$ & $19.37^{[19.3619 .37]}$ \\
\hline Center Longitude $\left({ }^{\circ}\right.$, West $)$ & $155.302^{\lfloor 155.301155 .3\rfloor}$ \\
\hline RMS error (mm) & 3.5 \\
\hline
\end{tabular}

Table 2. Best fit parameters for the preferred models in Period 1 and 2 given with their $95 \%$ confidence intervals following [Sambridge, 1999a].* denotes a parameter which was fixed during inversions. 